\title{
Agata SOWIŃSKA
}

(Katowice, UŚ)

\section{ZNACZENIE EGIPTU W APOKALIPTYCE

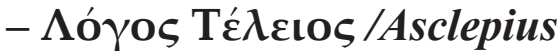 (NHC VI, 8: 70,3-76,1; Ascl. 24-27)}

Od początku naszej ery zarówno Żydzi, jak i chrześcijanie terminem ,apo-

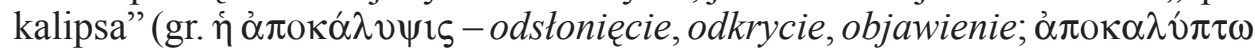
- odkrywam, odstaniam, objawiam ${ }^{1}$ ) określali księgę zawierającą objawienia Boże, dotyczące głównie przyszłości. Zbiór takich ksiąg pozabiblijnych pochodzenia żydowskiego nazwany został literatura apokaliptyczną, albo po prostu apokaliptyką ${ }^{2}$, stanowiąca gatunek piśmiennictwa religijnego, uprawiany w judaizmie i w okresie wczesnego chrześcijaństwa (zwłaszcza w II w. i III w.). Do niej, zwłaszcza starotestamentalnej, zaliczyć można m.in. następujące księgi: Henocha etiopska, Henocha słowiańska lub tajemnic Henocha, Henocha hebrajska, Jubileusze, Testamenty 12 Patriarchów, Psalmy Salomona, Księgi Sybillińskie, Wniebowzięcie Mojżesza, syryjska Apokalipsa Barucha, grecka Apokalipsa Barucha, Apokalipsa Abrahama, Apokalipsa Mojżesza oraz Apokalipsa Eliasza, Sofoniasza i Ezechiela ${ }^{3}$.

Cechami charakterystycznymi apokaliptyki są anonimowość i ezoteryzm, ponieważ nieznany autor wkłada $\mathrm{w}$ usta jakiejś słynnej postaci $\mathrm{z}$ odległej przeszłości treść objawienia, udzielonego jej przez samego Boga i każe się domyślać, że to pismo było znane już wcześniej, ale tylko osobom wtajemniczonym, zanim dostało się w ręce szerszych kół czytelników. Co więcej, autor $\mathrm{w}$ formie proroctwa przedstawia historię danego narodu (vaticinium post eventum), np. żydowskiego, na podstawie opowiadań biblijnych. Do czasu życia autora ów przegląd historyczny jest w mniejszym lub większym stopniu prawdziwy. Później natomiast rozpoczynają się przepowiednie o charakterze eschatologicznym, oparte na różnych często sprzecznych ze sobą podaniach o końcu świata i sądzie, nagrodzie i karze, o nowym świecie. Generalnie, trudno odróżnić, co należy do przeszłości, a co do przyszłości, ponieważ wszystko jest tu zagadkowe (np. wzmianki historyczne). Ponadto literatura apokalip-

\footnotetext{
${ }^{1}$ Por. O. Jurewicz, Stownik grecko-polski, t. 1, Warszawa 2000, 89.

${ }^{2}$ Por. J. Stępień, Apokaliptyka, w: Podręczna encyklopedia biblijna, red, E. Dąbrowski, Poznań - Warszawa - Lublin 1959, 71.

${ }^{3}$ Por. tamże, s, 38.
} 
tyczna zawiera w sobie symbolizm oraz determinizm. Utwór taki jest pełen liczb, tajemniczych porównań zestawianych często w sposób nad wyraz fantastyczny, a w aspekcie historycznym widać wyraźnie jeden ustalony schemat, oparty na spekulacji kosmologicznej.

Przykładem powyższej charakterystyki literatury apokaliptycznej może być, wspomniana już wcześniej, apokryficzna Apokalipsa Eliasza, datowana na lata 150-275 po Chrystusie, we fragmencie której czytamy:

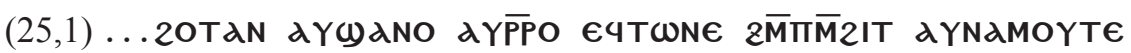

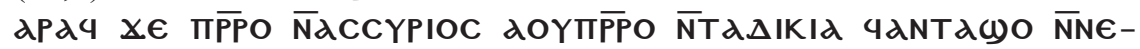

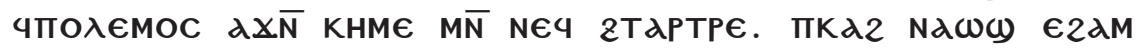

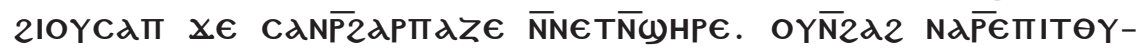

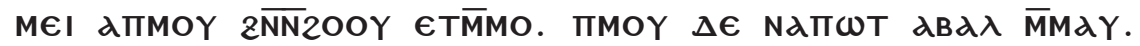

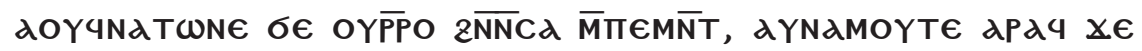

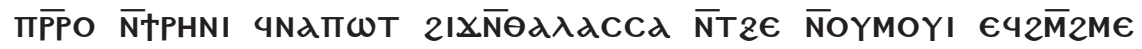

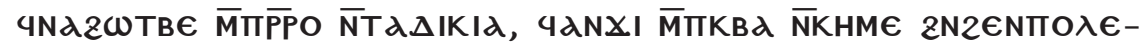

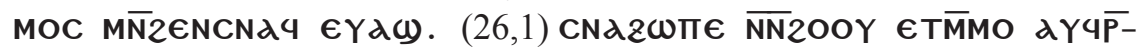

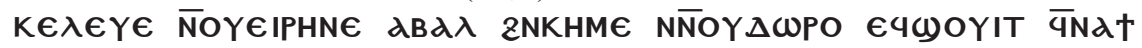

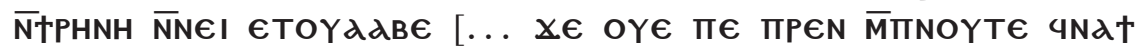

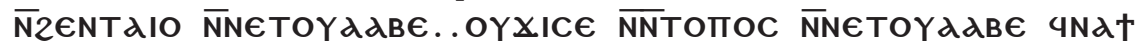

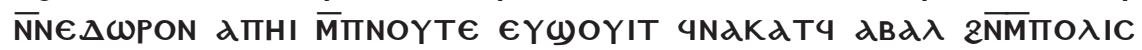

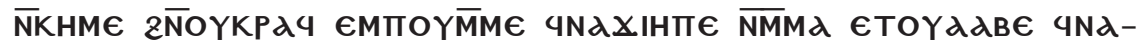

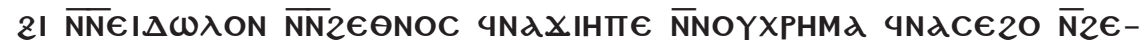

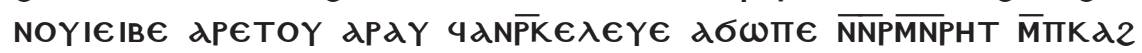

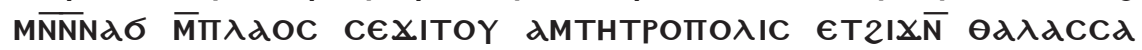

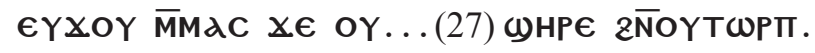

„(25, 1) .... Gdy zobaczą króla, jak powstaje na północy, to będą go nazywać królem Assyryjczyków i królem niesprawiedliwości; uczyni wiele swych wojen na ziemi Egiptu, i swego zamętu. Ziemia będzie jęczeć wówczas gdy zabiorą wasze dzieci. Wielu będzie chciało umrzeć w owych dniach. Śmierć jednak ucieknie stamtąd. I powstanie król w okolicach Zachodu, król, którego będą nazywać królem pokoju, pobiegnie po morzu jak ryczący lew i zabije króla niesprawiedliwości, weźmie pomstę za Egipt i za wojny i wiele przelanej krwi. $(26,1)$ Stanie się w owych dniach, że nakazany będzie pokój z Egiptu i znakomity dar, dany będzie pokój świętym, [...], gdy zostanie powiedziane: Jedno jest imię Boga. (Egipt?) odda cześć świętym. Ustanowienie miejscom świętym, da czcze podarunki dla domu Boga, odwróci się podstępnie od miast Egiptu, tak, że (tego) nie zauważą, policzy miejsca święte, zajmie bóstwa pogan, będzie obliczał ich skarby, ustanowi dla nich kapłanów, nakaże im porwać sieroty ziemi i możnych ludu, aby zaprowadzić ich do miasta nad morze, gdy powie... (27) rabunek synów"4.

\footnotetext{
${ }^{4}$ Apocalypsis Eliae 25, 1 - 27, 1, ed. G. Steindorff, Die Apokalypse des Elias, eine unbekannte
} 
Mowa tutaj o wojnach prowadzonych w granicach Egiptu przez Assyryjczyków. Są to fakty dokonane w przeszłości, jednak występują w Apokalipsie Eliasza jako czynność mająca dopiero nastapić, stąd można mówić o charakterystycznym dla apokaliptyki vaticinium post eventum. Walka rozegra się

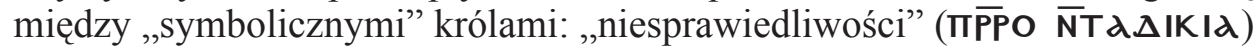

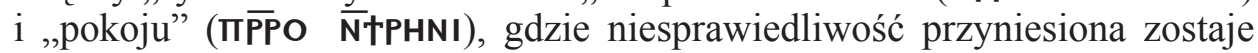
z zewnątrz i niesie ze sobą wojny i śmierć; ,pokój” natomiast pokonując „króla niesprawiedliwości”, pokonuje równocześnie wielobóstwo stwierdzając, że

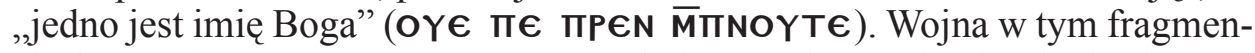
cie łączy się zatem z pogaństwem, pokój natomiast staje się ekwiwalentem monoteizmu. Egipt więc, początkowo ma być spowity chaosem za sprawą, być może, pogaństwa. Wyzwolenie dopiero ma być przyniesione przez „,cześć dla Jednego Boga". Przemiana jednak egipskiego świata politeistycznego w monoteizm wydaje się równie gwałtowna, np. zajęcie bóstw pogan, porywanie sierot, możnych i doprowadzenie ich do bliżej nieokreślonego miasta nad morzem, być może do Aleksandrii. Ziemia egipska staje się areną walki między pogaństwem a wiarą w Jednego Boga, co pokazuje następny passus:

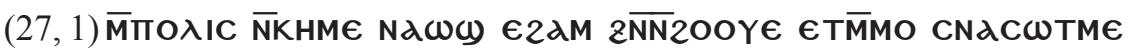

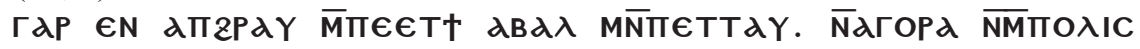

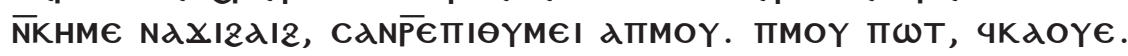

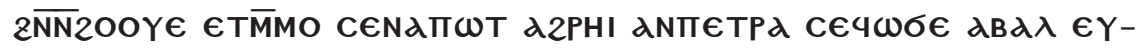 XOY MMAC X€ $2 \epsilon I \epsilon ~ d Z P H I ~ d X \omega N$ dOY dN NOYMOY. OY

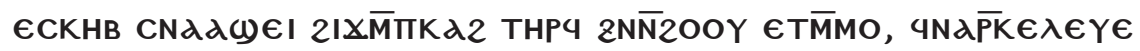

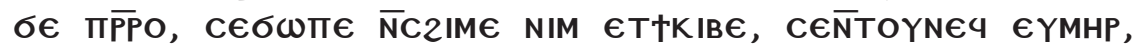

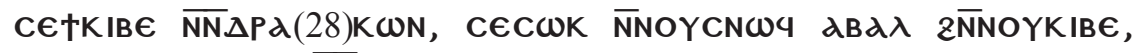 c€T€OY€ dNK $\lambda$ ONNCגTd.}

„Miasta Egiptu będą jęczeć w owych dniach, gdyż nie będą słyszeć głosu sprzedającego i kupującego. Targowiska miast Egiptu będą pokryte pyłem. Będą płakać razem, ci, którzy pozostaną w Egipcie. Zapragną śmierci, ale śmierć ucieknie i ich opuści. W owych dniach na skały i będą (z nich) zeskakiwać wołając: „,padnijcie na nas” i nie zaznają śmierci. Wielokrotne udręczenie będzie się zwiększać na całej ziemi w owych dniach. Król wyda rozkaz, aby pochwycić wszystkie kobiety, które karmią, aby zostały przy nim (?) związane, aby karmiły węże (28), które ssać będą krew z ich piersi, aby je oddano (w końcu? płomieniom) ognia" [tłum. W. Myszor $]^{5}$. ,jako truciznę do strzał" [tłum. D. Frankfurter] ${ }^{6}$.

Apokalypse und Bruchstücke der Sophonias-Apokalypse, TU 17, Leipzig 1899, $76-85$ (+ przekład niemiecki), tłum. W. Myszor w rękopisie; całość Apokalipsy Eliasza (s. 34-145) wg dwóch rękopisów: achmimicznym, s. 34-108, sahidycznym, s. 110-145.

${ }^{5}$ Apocalypsis Eliae 27, 1 - 28, 1, ed. Steindorff, s. 78-80.

${ }^{6}$ Por. D. Frankfurter, Elijah in Upper Egypt. The Apocalypse of Eliah and early Egyptian Christianity, Minneapolis 1993, 309. 
W tym fragmencie widać wyraźnie, że Egipt staje się krajem cierpienia. Egipcjanie będą pragnęli śmierci, wołając do kamieni, aby te na nich padły (co jest elementem biblijnym), jednak ludzie śmierci nie zaznają. Cierpienie Egiptu tym bardziej jest ukazane przez dręczenie kobiet, spośród których cieszyć się będą jedynie te, które nigdy nie poczęły lub są niepłodne (element biblijny), co przekazuje nam kolejny passus Apokalipsy:

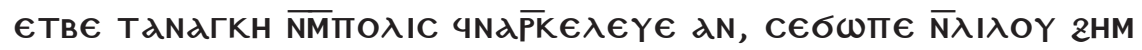
NIM $X \bar{N} \overline{M M} \bar{N} T C N \alpha Y C$ NPMT€ C€ZPHI C€T€OY€ dT€BdY $\alpha \dagger \bar{K} C d T \epsilon$.

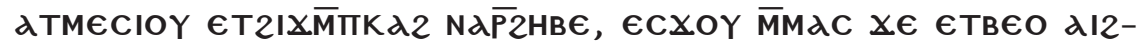

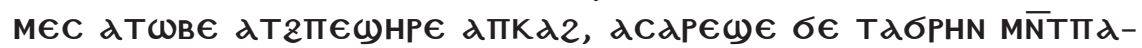

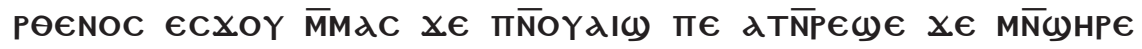

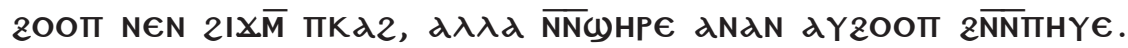

„Z powodu losu miast postanowi znowu, aby porwano wszystkie dzieci poniżej dwunastu lat $\mathrm{i}$ aby je wydano temu [...], dla wrzucenia do ognia [tłum.W. Myszor]/ dla nauki rzucania strzałami [tłum. D. Frankfurter] . Położna tego kraju będzie biadać, a ta, która urodziła wzniesie oczy w niebo wołając, «dlaczego poczęłam (?), aby dzieci wydać na ziemię?» Będzie się cieszyć niepłodna razem z dziewica, gdy powiedzą: «To nasz czas, abyśmy się cieszyły, że nie ma na ziemi dla nas dzieci, ale że nasze dzieci są w niebiosach»""7.

Głębsze znaczenie powyższych fragmentów ukazuje David Frankfurter stwierdzając, że okrutna rola „złego króla” sygnalizuje, iż dany ustęp w tekście powinien być rozumiany jako daleko posunięta „napaść" na macierzyństwo w tym okresie. Wizerunek kobiety zmuszonej do karmienia węży zyskał dużą popularność w Egipcie, ukazując wyjątkową symbolikę nawiązującą do kultury egipskiej. Jej znaczenie dla ludności zromanizowanego Egiptu można przybliżyć przez analizę symboliki węży, piersi, mleka z piersi kobiety, krwi oraz trucizny. To właśnie wspomnienie o truciźnie ostrzega, że znaczenie passusu 28 może mieć związek z egipskimi zaklęciami rytualnymi. Koptyjskie słowo $\mathrm{K}_{\boldsymbol{\lambda} \mathrm{O}^{8}}$ odnosiło swoją nazwę do trucizny pochodzenia roślinnego, w opozycji do, na przykład, jadu węża i tym samym do substancji zebranej i dostarczonej przez znawcę; $\varphi \alpha ́ \rho \mu \alpha \kappa o v$ - grecki odpowiednik danego słowa (występujący w transkrypcji greckiej Apokalipsy Eliasza) używany był jako nazwa zarówno środka leczniczego, jak i różnego rodzaju trucizn spreparowanych przez mistrzów magii.

Badanie egipskich zaklęć od czasów klasycznych do okresu grecko-rzymskiego odsłania ogromne zainteresowanie metodami zapobiegania ukąszeniom węża i ogólnie - do poskramiania czy odpychania węży. Zaklęcia tego typu podnosiły niekiedy to zainteresowanie do bardziej mitycznego zakresu

\footnotetext{
${ }^{7}$ Apocalypsis Eliae 28, 3-17, Steindorff, s. 80-82.

${ }^{8}$ Por. W.E. Crum, A Coptic Dictionary, Oregon 2005, 102: „, K $\lambda \mathrm{O}$ - vegetable poison used for arrows".
} 
pokonania Apopisa, ale zazwyczaj dawały obraz węży jako rozszerzenie peryferyjnej sfery Seta-Tyfona. Wąż wyłania się z takich tradycji jako figura wysoce symboliczna: archetyp zła na ziemi egipskiej.

Piersi symbolizowały najbardziej delikatną (wrażliwą) część kobiety-matki. Szczegółowe zaklęcie z medycznych korpusów rytualnych (the ritual-medical corpora) przywołuje Izydę jako matkę Horusa, aby chroniła piersi kobiety przed ,zmarłym mężczyzną i zmarłą kobietą"(a male dead and a female dead), czyli dwoma specyficznymi demonami. Ma to najprawdopodobniej związek z zaklęciem pochodzącym z Tekstów Sarkofagów: „Kobieta nie może być pożarta/ukąszona przez węża" (That a woman may not be eaten by a snake). Ten bezwzględny akt przystawiania węży do piersi kobiety stanowił niewyobrażalny horror, który mógł się wydarzyć w czasach nieszczęścia pod panowaniem tyrana. Jego następstwem jest płynąca z piersi krew, która ma symboliczną wartość, jako magiczna substancja w egipskim rytualnym symbolizmie. Apokalipsa Eliasza nawiązuje tu do krwi eschatologicznej heroiny-męczennicy Tabithy (the blood of eschatological heroine-martyr Tabitha), jako lekarstwa dla ludzi, co najprawdopodobniej stanowi kontynuację starszej tradycji, dotyczącej bogini pod postacią skorpiona Ta-Bitjet, dzięki krwi której Horus został powołany do leczenia ukąszeń zadanych przez skorpiona.

Mleko z piersi kobiety uważane było również za substancję magiczna, jednak zastapienie mleka krwią, pomimo świętości jednej i drugiej substancji, było przerażające: jak mówi zaklęcie do obrony piersi: „Nie wytwarzajcie krwi!". To właśnie ta makabra doprowadziła przypuszczalnie do stworzenia i przenoszenia interesującej legendy w arabskiej Historii Patriarchów Aleksandryjskich, zgodnie z którą kobieta chrzci swe dzieci namaszczając je kroplami krwi ze swej piersi, którą wcześniej sobie obcina ${ }^{9}$. Podobnie jak w Apokalipsie Piotra, która opisuje, jako kwaśne, mleko wyprodukowane przez kobiety w piekle, których piersi są atakowane przez zwierzęta ${ }^{10}$. W tej pełnej martyrologii legendzie mleko negowane jest jako pozytywny symbol macierzyństwa: to krew staje się uświęconą substancją. W przeciwieństwie do Apokalipsy Eliasza, która przypisuje całkiem negatywne znaczenie pozyskiwaniu krwi z piersi kobiet ${ }^{11}$.

Tragedia rozgrywająca się na ziemi egipskiej przewija się przez kolejne fragmenty apokalipsy, opatrzone dodatkowo symboliką liczb, które brzmią:

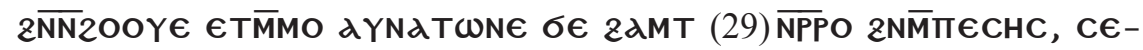

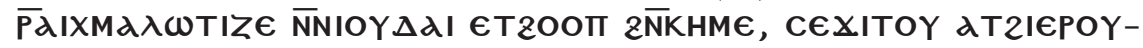

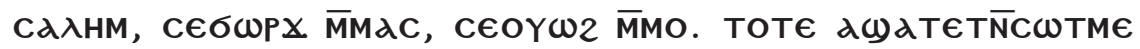

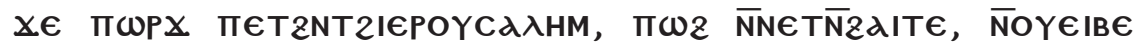

${ }^{9}$ Por. Historia Patriarcharum Alexandrinorum, ed. B. Evetts: History of the Patriarchs of the Coptic Church of Alexandria. Peter I to Benjamin I (661), PO 1, Paris 1907, 386.

${ }^{10}$ Por. Apocalypsis Petri (fragm.), w: Clemens Alexandrinus, Eclogae 49, PG 9, 720C.

${ }^{11}$ Por. Frankfurter, Elijah in Upper Egypt, s. 207-210. 


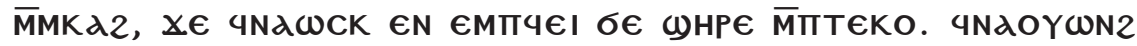

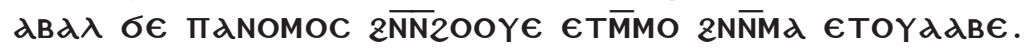

„W owych dniach powstaną trzej (29) królowie wśród Persów i wezmą w niewolę Żydów, którzy są w Egipcie i powiodą ich do Jerozolimy, aby (ją) zasiedlić i aby tam mieszkali. Jeśli posłyszycie, że jest spór w Jerozolimie, to rozdzierajcie wasze szaty, wy kapłani ziemi, gdyż wnet przyjdzie syn zniszczenia. Objawi się w owych dniach w miejscach świętych"12.

Po pierwsze spotykamy się tutaj z typową cechą apokaliptyki czyli z symbolizmem: „trzej królowie”, „syn zniszczenia”. Po drugie, niewola Żydów, ich prześladowanie w Egipcie, postrzegana może być jako vaticinium post eventum. Jest to fakt pokazujący Egipt w negatywnym świetle, przypominający Egipt biblijny:

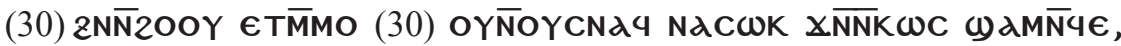

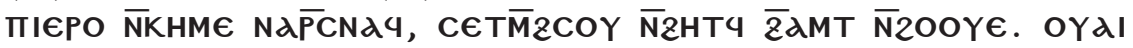
$\overline{N K H M \epsilon ~ M \bar{N} N \epsilon T \bar{N} Z H T \varphi . ~}$

(30) „W owych dniach krew będzie wylana od Kos do Memfis, rzeka Egiptu spłynie krwią tak, że przez trzy dni nie będzie można z niej pić. Biada Egiptowi i tym, którzy w nim mieszkają"13.

Tak mówi Eliasz i dodaje:

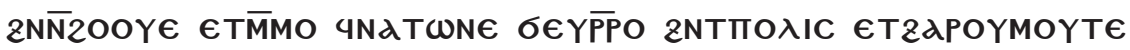

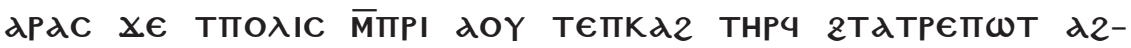

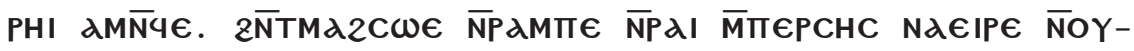

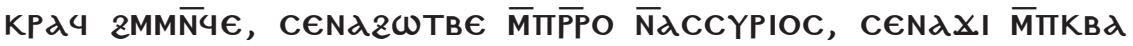

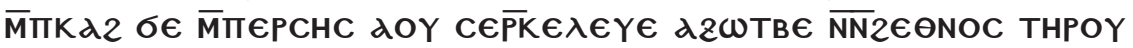

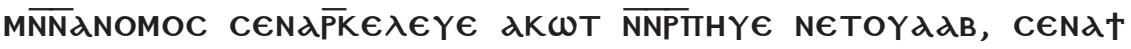

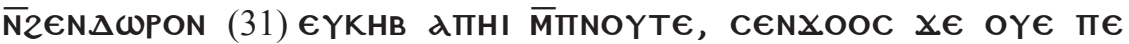

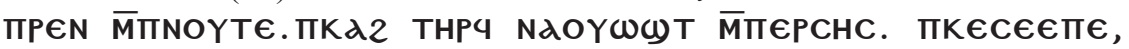

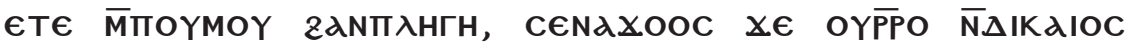

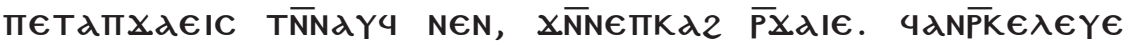

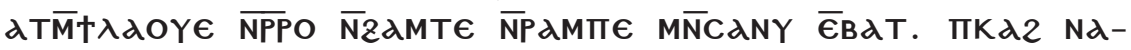

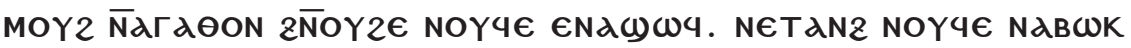

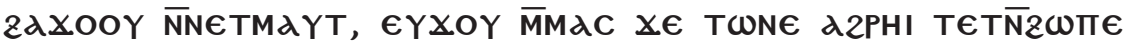

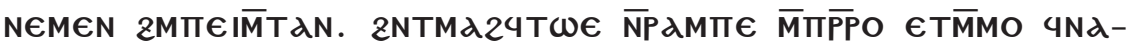

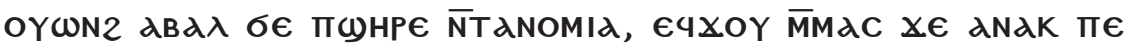

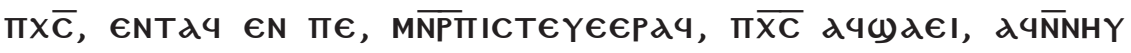

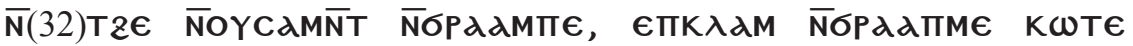

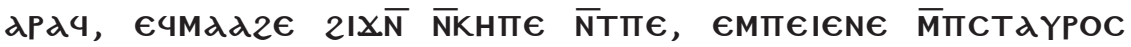

${ }^{12}$ Apocalypsis Eliae 29, 1-18, Steindorff, s. 82-84.

${ }^{13}$ Tamże 30, 1-5, Steindorff, s. 84. 


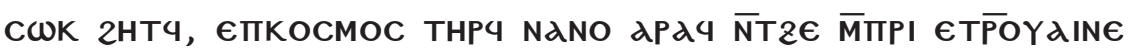

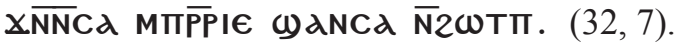

„[...] W owych dniach podniesie się król w mieście, które nazywa się «miastem słońca» i cały kraj zadrży i będą uciekać aż do Memfis. W szóstym roku królowie perscy wezmą podstępnie Memfis, zabiją króla Assyryjczyków i Persowie wezmą pomstę za (ten) kraj, nakażą zabijać wszystkich pogan i bezbożników, nakażą odbudować święte świątynie, przyniosą podwójne dary (31) do domu Bożego mówiąc: «Jedno jest imię Boga». Cała ziemia będzie posłuszna Persom. A inni, pozostali, którzy nie zginęli pod ciosami będą mówić: «Sprawiedliwy jest ten król, którego Pan nam posłał, aby kraj nie został zamieniony na pustynię». Nakaże, aby przez trzy lata i sześć miesięcy nie dawać królowi (podatku?). Kraj napełni się dobrami w wielkiej szczodrobliwości. Żyjący wyjdą naprzeciw umarłym mówiąc im: «powstańcie i przybywajcie z nami w tym pokoju». W czwartym roku (panowania) tego króla, objawi się Syn bezprawia, gdy powie: «Ja jestem Pomazańcem» chociaż nim nie jest. Nie wierzcie mu. Bo gdy Pomazaniec przyjdzie, (32) w postaci gołębicy, gdy wieniec gołębi go otoczy, gdy pojawi się na obłokach niebieskich, to przed nim poniosą znak krzyża, jak świecące słońce od rejonu wschodu słońca, aż po rejon zachodu słońca"14.

W swych słowach prorok ukazuje sytuację Egiptu pod zaborem perskim (Persowie - poganie, paradoksalnie, będą zabijać pogan i bezbożników) i jednocześnie daje obraz (symbolizm) pomazańca ( $\Pi \overline{\mathbf{X C}})$ fałszywego ,syna bezprawia" (пஸे czas panowania króla, najprawdopodobniej, perskiego, który ma „,podnieść się” z „miasta słońca” (przypuszczalnie Heliopolis). Wybawieniem wydaje się być dopiero ,pomazaniec prawdziwy”, w postaci gołębicy z krzyżem, co jest nawiązaniem do chrześcijaństwa.

Apokalipsa Eliasza, będąca w nurcie biblijnym pod względem stylu i intencji autora, pełna jest symboliki liczbowej oraz elementów biblijnych. Występują w niej informacje sprzeczne z faktami: zdarzenia historyczne stają się dopiero ich zapowiedzią (vaticinium post eventum). Można również powiedzieć o elemencie soteriologicznym, który przedstawia się w postaci „Pomazańca” - gołębicy, na „obłokach niebieskich”, który jest przeciwieństwem „syna bezprawia”. Eliasz pokazuje w proroctwie Egipt uciemiężony, pełen chaosu, spowodowanego przez nieustanne wojny rozgrywające się na jego terenie. Można powiedzieć, że znaczenie Egiptu jest tutaj w gruncie rzeczy negatywne, biblijne, ze względu na ewidentne cierpienie ludzi, które przewija się w poszczególnych wersach utworu.

Widocznym elementem w Apokalipsie Eliasza jest opis chaosu, czyli tzw. Chaosbeschreibung (termin stworzony przez Jana Assmanna ${ }^{15}$ ) powstały na

\footnotetext{
${ }^{14}$ Tamże 30, 5 - 32, 7, Steindorff, s. 84-86.

${ }^{15}$ Por. J. Assmann, Königsdogma und Heilserwartung: Politische und kultische Chaosbeschrei-
} 
gruncie ideologii władzy w starożytnym Egipcie oraz widoczny dzięki formom literackim, wykorzystywanym przez skrybów do gloryfikacji i definiowania akcesji władców. Ze względu na wzrastające kontrowersje, związane z władzą w okresie hellenistycznym, skrybowie z różnych (często pozostających ze sobą w konflikcie) świątyń zaczęli nostalgicznie odwoływać się do paradygmatów prawdziwej władzy z zamierzchłych legendarnych czasów i optymistycznie zwracać się do przyszłości z prośbą o faraona „mesjasza”. I jedna i duga perspektywa rzucała mroczne światło na czasy im współczesne, czasy bezprawnego panowania lub jego braku. Skrybowie zaczęli opisywać ten okres chaosu nomenklatura i motywami tradycyjnie wykorzystywanymi do charakterystyki okresu interregnum, co dziś określamy terminem: Chaosbeschreibung ${ }^{16}$. Elementy składowe, motywy, ,opisu chaosu” uczeni podzielili na cztery grupy: 1. Chaos in Society, 2. Chaos in Earth, 3. Collapse of Borders, 4. Chaos in the Heavens. Poszczególne punkty zawierają dodatkowo podgrupy, wiążące się merytorycznie z przypisywaną im daną tragedią (chaosem $)^{17}$. Dlatego odrodzenie się w Apokalipsie Eliasza wielu antycznych motywów profetycznych potwierdza ważną historyczną tezę, że taki proces komponowania danych tekstów przez okres panowania rzymskiego w Egipcie znajdowano $w$ tekstach antycznych i legendach. Był on świadomie wplatany w pisma i nieustannie aktualizowany.

Użycie Chaosbeschreibung w Apokalipsie Eliasza jest i implicytne i eksplicytne. Fakt, że te przerażające czyny wynikają bezpośrednio z braku ciągłości, czy sukcesji na tronie Egiptu, implikuje kontynuację ideologii egipskiego panowania w opisie nieszczęść w Apokalipsie Eliasza. Szczegóły dotyczące losu kobiet i macierzyństwa w tych czasach przywołuje natomiast podstawowy motyw Chaos in Society w Chaosbeschreibung, chociaż należy przyznać, że passus odnoszący się do lamentu matek i radości dziewic czy bezpłodnych kobiet rodzi podobieństwo do ówczesnej literatury żydowskiej odnoszącej się do eschatologii.

Eksplicytne wykorzystanie Chaosbeschreibung ukazuje się w wyobrażeniu Nilu, suszy i głodu, w opuszczaniu miast (Aleksandria) i w obracaniu ich w pył, czy w motywach samobójczych: te obrazy były powszechne w kulturze Egiptu. One ukonstytuowały pierwotne symbole w ramach kultury literackiej Egiptu dla ukazania społecznego i kosmicznego rozpadu i załamania. Były tymi symbolami, do których przyzwyczajona była głównie niepiśmienna kultura egipska; w swej recepcji i rozumieniu wyroczni oraz w związanej z tym propagandzie. W okresie grecko-rzymskim tradycyjna wymowa Chaosbeschreibung funkcjonowała $\mathrm{w}$ celu umiejscowienia danego materiału w życiu,

bung in ägyptischen Texten, w: Apocalypticism in the Mediterranean World and the Near East, ed. D. Hellholm, Tübingen 1983, 345-377.

${ }^{16}$ Frankfurter, Elijah in Upper Egypt, s. 161.

${ }^{17}$ Por. tamże, s. 183. 
uczuciach i symbolicznym świecie Egipcjan ${ }^{18}$.

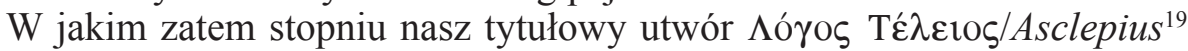
zbliżony jest do ksiag objawionych, zwłaszcza w części, którą nazywamy „apokalipsą"? Nazywany jest apokalipsą, jednak nie jest wymieniany pośród szerzej znanych pism literatury apokaliptycznej. Z niewyjaśnionych przyczyn wpleciony został do utworów gnostycznych biblioteki z Nag Hammadi, będąc jednocześnie pismem z zakresu hermetyzmu, najprawdopodobniej, wyższego, którego transkrypcja w systemie dwu- a nawet trójjęzycznym (język grecki, łacina, język koptyjski) przetrwała do naszych czasów. Dokładna treść oraz interpretacja apokalipsy zbliży nas do odpowiedzi na pytania, dotyczące jej znaczenia dla kultury egipskiej: Co łączy nasz utwór z apokryficzną apokalipsą której przykładem jest przytoczona powyżej Apokalipsa Eliasza: treść czy tylko forma wypowiedzi? Czy kultura Egiptu, postrzegana jako symbol zła i niewoli pośród przodków chrześcijan, znajdzie potwierdzenie takiego stanowiska w apokalipsie Hermesa Trismegistosa - proroka?

Apokaliptyczny tekst hermetyczny, zakorzeniony głęboko we wspomnianej już tradycji Chaosbeschreibung, zaczyna się następującymi słowami:

NHC VI 8: 70, 3 - 70, 10

$70[\overline{0}]$

$3 \quad H \in[K \epsilon \bar{N} \alpha] T \operatorname{CoOYN} \omega[\lambda]] K \lambda H$

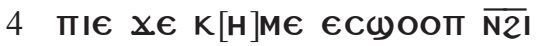

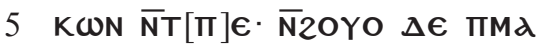

$6 \overline{\mathrm{N}} \omega \omega \pi \epsilon \overline{\mathrm{N} T \pi \epsilon}$ T€ $\overline{\mathrm{MN}} \mathrm{N} \in \mathrm{N} \in \mathrm{P}$

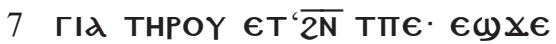

$8 \epsilon \omega \omega \epsilon \in T P \in N X \omega \bar{N} T M \epsilon \cdot \pi \bar{N}$

9 Ka2 $€$ ч以

10 MOC.
Asclepius Latinus 24

„An ignoras, o Asclepi, quod Aegyptus

imago sit caeli, aut, quod est verius

translatio aut descensio omnium

quae gubernantur atque exercentur in caelo?

Et si dicendum est verius, terra nostra mundi totius est templum ${ }^{20}$

„(3) Czy nie wiesz, Asklepiuszu, (4) że Egipt jest obrazem (5) nieba, co więcej (6), jest siedzibą nieba wraz ze (7) wszystkimi mocami, które są w niebie;

\footnotetext{
${ }^{18}$ Por. tamże, s. 210.

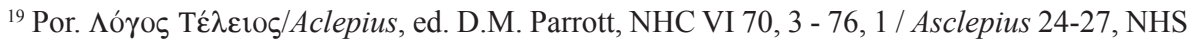
11, Leiden 1979, 418-439.

${ }^{20}$ NHS 11, 418 (wraz z wersją łacińską). Tekst i układ zapisu wszystkich fragmentów utworu według lekcji koptyjskiej i łacińskiej zgodnie z: J.P. Mahé, Le Fragment du Discours parfait et les Définitions Hermetiques Arméniennes, Québec 1978-1982, 169-195.
} 
jeśli (8) odpowiednim jest, żebyśmy mówili prawdę: nasza (9) ziemia jest świątynią świata" ${ }^{\prime 2}$.

Początkowe wersy utworu (NHC VI 8: 70, 3-10) przedstawiają niewatpliwie piękno egipskiego kraju, dając pozytywny wizerunek Egiptu. Egipt ukazywany jest jako obraz nieba $(70,4-5 \overline{\mathbf{N} 2} \mathrm{IK} \omega \mathbf{N} \overline{\mathbf{N} T}[\pi] \boldsymbol{\epsilon} /$ imago caeli $)$ i jednocześnie

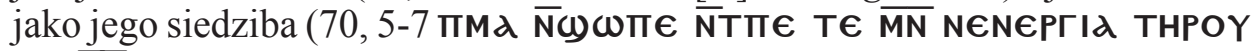
$\boldsymbol{\epsilon} \cdot \overline{\mathbf{N}} \mathbf{T} \boldsymbol{\top} \epsilon /$ translatio aut descensio omnium quae gubernantur atque exercentur in caelo). Już we wstępnych wersetach spotykamy sięz typowym dla apokaliptyki symbolizmem, odniesieniem do rzeczywistości, czym jest „obraz nieba”, ,siedziba nieba”. Przedstawienie bowiem Egiptu jako odzwierciedlenia sfery niebieskiej, może być związane ze świątynnym rytuałem, który miał nawiązywać do różnych przekształceń (70, 6-7 NENEPГId/ translatio aut descensio) zachodzących $\mathrm{w}$ niebie, a ziemskie skutki niebiańskich przyczyn miały zależeć od powodzenia danych rytuałów. W tym sensie zatem niebo i wszystkie zmiany w nim zachodzące, rzeczywiście mogły „zstępować” na ziemię, dzięki czemu Egipt stawał się ,świątynią (całego) świata” (70, 9-10 $\overline{\mathrm{NP}} \boldsymbol{\mathrm { N }} \epsilon \overline{\mathrm{M}}$ Космос $/$ terra nostra mundi totius est templum), ponieważ właśnie tam mieszkali wszyscy bogowie. Można dodać, że właśnie dzięki mnogości bóstw istniejących na ziemi egipskiej, była ona postrzegana jako kraj piękny i jedyny w swoim rodzaju, występując tutaj, mutatis mutandis, jako gloryfikacja wielobóstwa (pogaństwa). Jednak kraj nad Nilem nie będzie długo miejscem idyllicznym. Ogarnie go chaos, którego obraz przedstawia autor przepowiedni w wersetach NHC VI, 8: 70, 10-73, 22:

NHC VI 8: 70, 10 - 73, 22

Asclepius Latinus 24-26

$70[\overline{0}]$

$10 \epsilon \omega \omega \epsilon \Delta \epsilon \in \mathrm{POK} \in \overline{\mathrm{TMP}}$

11 ATCOOYN $X \in$ OY $\bar{N}$ OYOEIM

12 Nac)

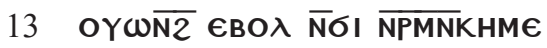

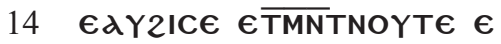

$15 \pi \times I N X H^{-}$

AYW TOYTPАГMATIA

16 THPC $\overline{2 \mathrm{~N}}$ TOYMNT'NOYTE CNA

$17 \omega \omega \pi \epsilon \in \mathrm{\epsilon} \omega \mathrm{HC}$.

TMNTNOYT€

Et tamen, quoniam praescire cuncta prudentes decet,

istud vos ignorare fas non est: futurum

tempus est quo

adpareat Aegyptios

incassum pia mente divinitatem

sedula religione servasse et omnis eorum sancta veneratio

in inritum casura frustrabitur. E terris,

${ }^{21}$ Własny przekład autorki artykułu. 


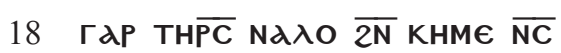

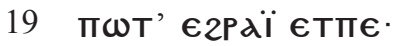

dYW KHM€

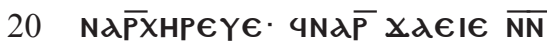

21 NOYT€ $\mathrm{NA \lambda \lambda O \phi Y \lambda OC} \mathrm{ГגP} \overline{\mathrm{N}}$

22 NHY €2OYN ЄKHM€ $\bar{N} C € \bar{P}$ XO

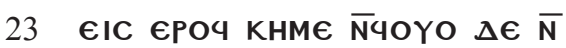

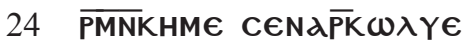

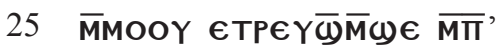

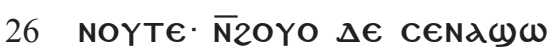

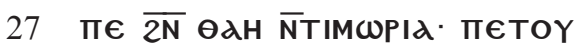

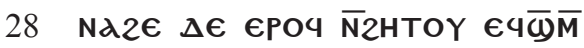

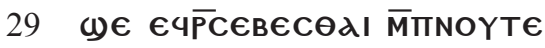

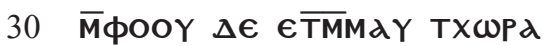

$31 \epsilon T \epsilon \overline{\text { NPMNNOYTE TIPA } \overline{\mathrm{N}} \times \omega}$

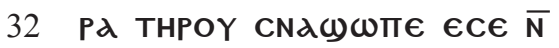

33 дсєвнС. OYКєТІ САMOY2

34 NPT

35 OYTE ECAMOYN2 AN NNOYTE

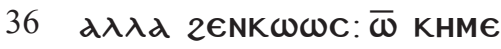

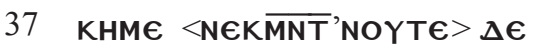

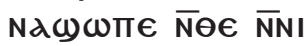

$38 \omega B \omega \omega c \cdot d Y \omega$ NEK' $\theta \epsilon I O N$ enim, et ad caelum recursura divinitas,

linqueterque Aegyptus terraque, sedes religionum quae fuit, viduata numinum praesentia destituertur. Alienigenis enim regionem istam terramque conpetentibus,

non solum neglectus religionum, sed, quod est durius, quasi de legibus a religione, pietate cultuque divino statuetur praescripta poena prohibitio.

Tunc terra ista sanctissima,

sedes delubrorum atque templorum, sepulcrorum erit

mortuorumque plenissima. O Aegypte, Aegypte, religionum tuarum solae supererunt fabulae, eaeque incredibiles posteris tuis solaque supererunt verba 
$3 \epsilon Y[O Y] d d[B]$ dY $\omega \in \omega[X]$

2€NWNE

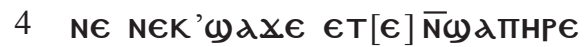

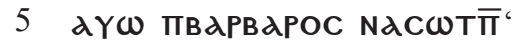

6 N2OYO ЄPOK'· $\overline{\mathrm{N} T O K}$ ' $\omega[\Pi] \mathrm{P} \overline{\mathrm{MN}}$

7 KHM€ $2 \overline{\mathrm{N}}$ T€чMN̄TNOYT€ $\overline{\mathrm{H}}$ OY

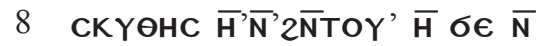

9 тєїмІNє. OY $\Delta \epsilon \pi \epsilon \dagger \Delta \omega \bar{M}$ MOч

$10 €$ €TPNKHM€ $\operatorname{C€NAK\omega ~ГגP~} \overline{\mathbf{N}}$

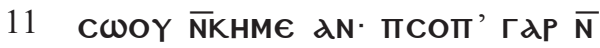

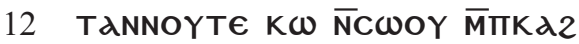

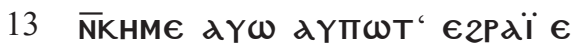

14 тпє тотє NPMNKHмє тнроү

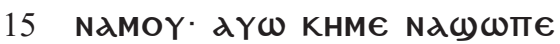

$16 €$ €щнРч $\overline{\mathrm{NNNOYT}} \overline{\mathrm{MN}} \overline{\mathrm{NP}} \overline{\mathrm{MN}}$

17 KHM€. '̄TOK' $\Delta €$

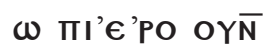

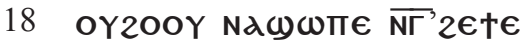

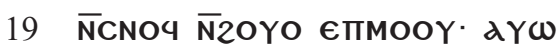

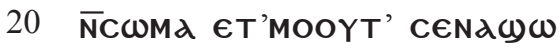

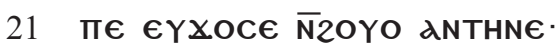

22 aYW CENAPIME dN MTTET'MO

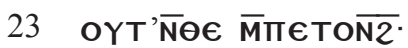

CENd

24 M€€Y€ M€N $€$ POY X€ OY $\overline{P M N}$

25 кнмє пє ЄТвє тєчдспє М lapidibus incisa,

tua pia facta narrantibus, et inhabitabit

Aegyptum

Scythes aut Indus aut aliquis talis id est vicina barbaria.

Divinitas enim

repetit caelum, deserti homines toti morientur atque ita Aegyptus, deo et homine viduata, deseretur. Te vero appello, sanctissimum flumen,

tibique futura praedico : torrenti sanguine plenus

adusque ripas erumpes undaeque divinae non solum polluentur sanguine, sed totae rumpentur et vivis multo maior numerus erit sepultorum; superstes vero qui foret, lingua sola cognoscetur Aegyptius, 
26 пмє2COா' CNdY.

27 А2POK' ЄKPIMє.

$\omega$ дсклнтіє

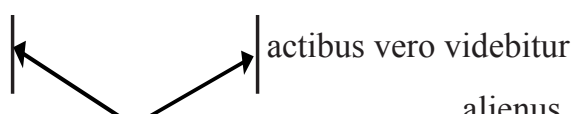
4NAOYW $\overline{N 2}$

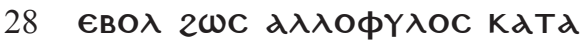

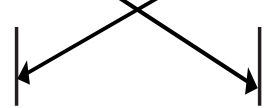

alienus. -25- Quid fles, o Asclepi?

29 Nєчгвноүє.

KHM€ $\bar{N} \Theta \epsilon I O N$

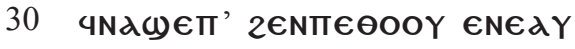
suadebitur inbueturque peioribus malis

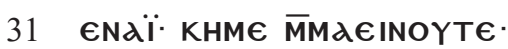
quae sancta quondam, divinitatis amantissima

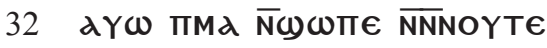
deorum in terras suae religionis merito sola deductio,

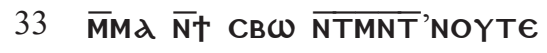
sanctitatis et pietatis magistra,

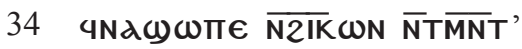
maxime $<$ in $>$ crudelitatis exemplum erit.

35 асєвнс.

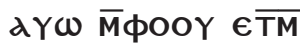

Et tunc, taedio hominum,

36 M€Y CENגP्PAYMA $2 N$

Мткосмос

non admirandus videbitur mundus

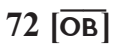

$1[+5] \overline{\mathrm{MN}} \mathrm{T} \overline{\mathrm{M}}\left[\overline{\mathrm{NT}}{ }^{\prime} \boldsymbol{d}\right] \mathrm{T}^{\prime}{ }^{\mathrm{N} O Y}[\mathrm{T \epsilon}]$.

2 oY[T€ C] nec adorandus.

$3 \lambda N[+5] \epsilon \in N X \omega \overline{M M}[O C \quad x] \epsilon N d$ Hoc totum bonum,

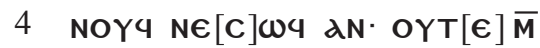
quo melius nec fuit nec

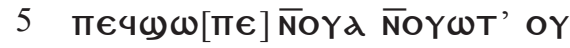
est nec erit

6 T€ $\bar{N} \theta \epsilon \omega[P] I d \cdot d \lambda \lambda d$ 4PKIN $\Delta Y$

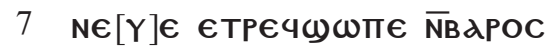

quod viderit possit, periclitabitur,

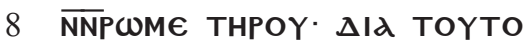
eritque grave hominibus ac, per hoc, 
9 CENגKגTAфPONI MMO4.

TKК

10 CMOC $€$ TN€CW4 $\overline{\mathrm{N}} \mathrm{T} €$ TNOY

11 тє. $\phi \omega в \epsilon \overline{\mathrm{MN}} \pi \epsilon \mathrm{T}^{\prime} \overline{\mathrm{TN} T} \omega \mathrm{N}$

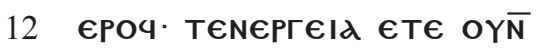

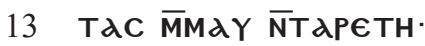

ө€WPId

$14 \epsilon$ Т $2 \overline{\mathrm{N}} 2$ д2 $\overline{\text { NсMOT' }}$

TXOPHГIA

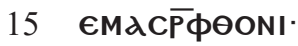

пєТ'мє2

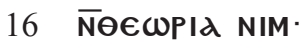

ceNגce $\overline{T \pi}$

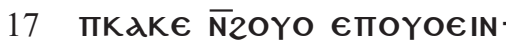

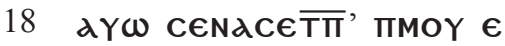

$19 \pi \omega \overline{N 2} \cdot \overline{M N} \lambda d d Y$ Nd€I $\overline{P M}$

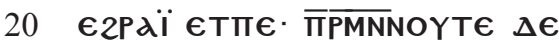

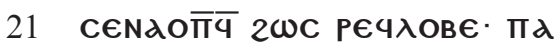

22 сєвнс $\Delta € \overline{\text { NP}}$

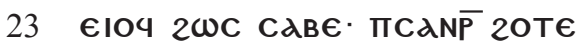

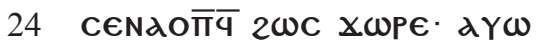

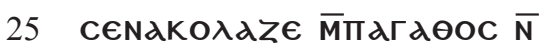

26 PWM 2WC PWM€ Є4200Y.

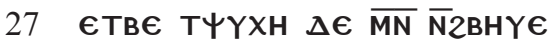

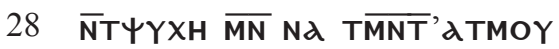

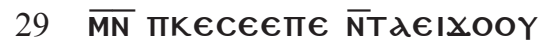

contemnetur; nec diligetur totus hic mundus, Dei opus inimitabile, gloriosa constructio, bonum multiformi imaginum varietate conpositum, machina voluntatis dei in suo opere absque invidia suffragantis, in unum omnium quae venerari, laudari, amari denique a videntibus possunt, multiformis adunata congestio. Nam et tenebrae praeponentur lumini et mors

vita utilior iudicabitur; nemo suspiciet caelum; religiosus pro insano, inreligiosus putabitur prudens, furiosus fortis, pro bono habebitur pessimus. Anima enim et omnia circum eam quibus aut inmortalis nata est aut inmortalitatem se consecuturam esse praesumit, secundum quod vobis exposui, 
$30 \epsilon$ P

31 MN AMMWN.

OY MONON CE

non solum

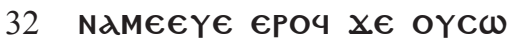

risui

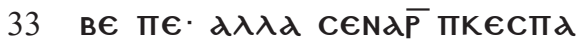

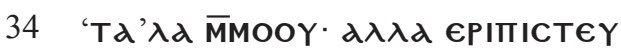

sed etiam putabitur

$35 \epsilon$ Naï $x \in$ Näi $\overline{N T \epsilon}$

vanitas. Sed mihi

36 бIN $\Delta Y N \epsilon Y \epsilon \overline{2 M} \Pi 2 d \epsilon \bar{N} \sigma I N \Delta Y$

credite:

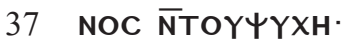

et capitale periculum

\section{NOC NTOYYYXH.} dYw ce

38 Na $\overline{C M N}$ OYNOMOC $\overline{\text { NBPP }}$ constituetur in eum qui se mentis religioni dederit. Nova constituentur iura, lex nova ;

$73[\overline{\mathrm{O}}]$

nihil sanctum, nihil religiosum

$1 \quad[\quad]$

$2[\quad] d N$

nec caelo nec caelestibus dignum

$3[ \pm 12 \quad$ dYW $\mathrm{C}] \in \mathrm{N} \alpha$

audietur aut mente credetur. Fit

$4[\mathrm{MOO}] \omega[\epsilon \in \mathrm{\epsilon} O \lambda \overline{\mathrm{N}} \sigma \mathrm{I} \overline{\mathrm{N}} \Delta \alpha I M] \omega N$

deorum ab hominibus dolenda

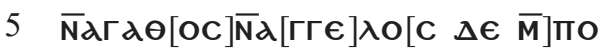

secessio; soli nocentes

6 NHPOC [C] $€ \mathrm{~N} \alpha \omega \omega \overline{\mathrm{x}} \bar{\Pi}, \mathrm{O}[\mathrm{Y}]$ angeli remanebunt $d €$ ТОМ

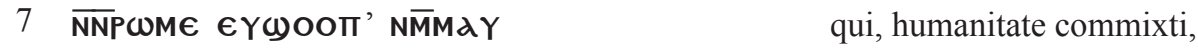

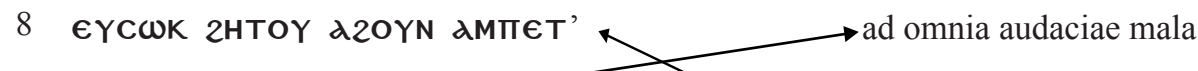

9 2OOY $\overline{2 \mathrm{~N}}$ OYTOХMHРId. dYw dZOYN

10 גN $\overline{M M T} '$ ' $2 € N T O \lambda €$ in bella,

11 MOC $\overline{\mathrm{MN}} 2 \in \mathrm{NT} \omega \overline{\mathrm{PT}}$, in rapinas, in fraudes €Y† СBW NaY et in omnia quae sunt animarum

$12 \epsilon \overline{2 M} \pi \alpha[P] \lambda \phi Y C I C \cdot \overline{2 N} \bar{N} 200 Y \epsilon$ naturae contraria. Tunc

13 TMMdY TKd2 NdC $\overline{M N T 4}$ dN. nec terra constabit 
14 dYW C€Ndח $\lambda \epsilon d$ dN $\overline{2 N} \Theta d \lambda d C C d$

15 OYTE CENACOYWN NCIOY dN

$16 \epsilon T^{\prime} \overline{2 N}$ Tாє СMH NIM €TOYגАB

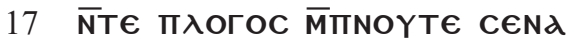

18 KגPWOY ЄРОч.

$\Pi$ ПגНP $\Delta \epsilon N \alpha \omega \omega$

$19 \mathrm{~N} \epsilon \cdot T d \ddot{I}$ T€ $\{$ T€ $\} \overline{\text { TMNT }}, \overline{2 \lambda \lambda O} \bar{M} \pi K O$

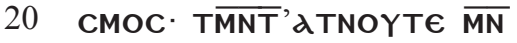

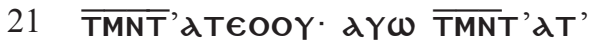

22 入оГОC NNWגХE ETNANOYOY. nec navigabitur mare nec caelum astrorum cursibus nec siderum cursus constabit in caelo; omnis vox divina necessaria taciturnitate mutescet fructus terrae conrumpentur nec fecunda tellus erit et aër ipse maesto torpore languescet. (26) Haec et talis senectus veniet mundi: inreligio, inordinatio, inrationabilitas bonorum omnium"22.

„70(10) I odpowiednim jest, żebyś ty (11) był świadomy, iż czas (12) nadejdzie, gdy (13) będzie się wydawać, że Egipcjanie, (14) służyli boskości (15) na próżno i cała ich działalność (16) związana z religią (17) zostanie wzgardzona. Boskość (18) bowiem cała odejdzie z Egiptu (19) i odleci w kierunku nieba, a Egipt (20) owdowieje; zostanie opuszczony przez (21) bogów; bowiem obcy (22) przyjdą do Egiptu i zapanują (23) nad nim. Co więcej, (24) Egipcjanie będą powstrzymywani przed (25) składaniem czci (26) bogu. Ponadto poniosa (27) okrutne kary; zwłaszcza gdy ktoś spośród nich (28) zostanie przyłapany składając cześć (29) miłującemu bogu. (30) W owym dniu ten kraj, (31) który jest najpobożniejszy pośród (32) wszystkich krajów, stanie się (33) bezbożny. Już dłużej nie będzie pełen (34) świątyń ale pełen grobów. (35) Ani nie będzie tym, który jest pełen bogów (36) ale jakichś zwłok. O Egipcie, (37) Egipcie! I < twoje bóstwa > będą niczym (38) baśnie, podobnie jak twoje kulty: 71 (1) Nie będzie się wierzyło (w?) (2) czyny cudotwórcze i słowa (3) święte, i także w kamienie, które są (4) twoimi słowami cudotwórczymi (5), a barbarzyńca będzie doskonalszy (6) niż ty, o Egipcjaninie, (7) przez swoją pobożność: czy to (8) Scyt, czy to Hindusi, czy inni (9) tego rodzaju. Dlaczego zatem mówię (10), o Egipcjaninie? Ponieważ oni (Egipcjanie) (11) również opuszczą Egipt. Raz bowiem, (12) bogowie opuścili ziemię (13) egipską i poszli do (14) nieba; wtedy wszyscy Egipcjanie (15) umrą i Egipt będzie (16) opuszczony przez bogów i (17) Egipcjan. I ty, święta rzeko, (18) nadejdzie taki dzień, kiedy spłyniesz (19) krwią raczej niż wodą. I (20) ciała

${ }^{22}$ NHS 11, 418-430 (wraz z wersją łacińską) 
zmarłych będą (21) unosiły się ponad brzegami. (22) I nie będzie opłakiwany umarły (23) tak, jak żyjący. (24) Egipcjanina pozna się jedynie (25) po jego mowie, (26) za drugim razem. - o Asklepiuszu, (27) dlaczego płaczesz? On (Egipcjanin) będzie jako (28) nieznajomy według (29) swoich czynów. Boski Egipt (30) znosić będzie cierpienia większe niż (31) teraz. Egipt, miłujący bogów; (32) i siedziba bogów, (33) i szkoła boskości (34) będzie obrazem (35) bezbożności; i w tym dniu (36) świat nie będzie podziwiany. 72 (1) i bezbożność, (2) ani nie będzie się czciło...(3) ...o czym się mówi, że jest [nie jest] (4) dobre, jest też piękne. Przestało być i (5) czymś pojedynczym i (6) wizją, ale ryzykuje tym, że (7) stanie się ciężarem (8) wszystkich ludzi. Dlatego (9) zostanie wzgardzony; (10) piękny świat boga,(11) dzieło, które nie ma sobie równych (12) moc, która jest pełna (13) cnoty; wizja, (14) która posiada wiele form; choregia, (15)która nie zazdrości, która jest pełna (16) każdej wizji. Będzie preferowana [dosł. wybierana] (17) ciemność raczej niż światłość;(18)i będzie wybierana raczej śmierć niż (19) życie. Nikt nie spojrzy (20) w niebo; natomiast człowiek pobożny (21) będzie postrzegany jako szaleniec; (22) bezbożnik zaś (23) czczony będzie jako mędrzec; tchórz (24) uważany będzie za człowieka dzielnego; i (25) człowiek dobry oskarżany będzie (26) jak przestępca.(27) Jeśli chodzi o duszę i rzeczy (28) związane z duszą jak i z nieśmiertelnością (29) oraz sprawy pozostałe, o których wam (30) powiedziałem, o Tacie, Asklepiuszu (31) i Ammonie; nie tylko one (32) będą wydawały się śmieszne, (33) ale będą uważane za zbytek; (34) lecz uwierzcie mi, (35) że (ludzie) tego rodzaju (36) będą zagrożeni największym niebezpieczeństwem (37) pod względem ich duszy. I (38) nowe prawo zostanie sporządzone. 73 (1) [...] (2) [...] (3) [..] i (4) odejdą dobrzy bogowie; (5) natomiast anioły (6) złe pozostaną (7) z ludźmi, mieszkając z nimi (8), doprowadzając ich do złych czynów (9)zuchwale; i do (10) bezbożności, i wojen, i (11) do rozbojów, ucząc ich (12) tego, co jest sprzeczne z naturą. W owych dniach (13) ziemia nie będzie stabilna; (14) i nie będzie się pływało po morzu (15), ani nie będzie się rozpoznawało gwiazd (16) na niebie; każdy głos święty (17) słowa Bożego (18) zostanie wyciszony, a powietrze (19) będzie zanieczyszczone. Taka jest starość (20) świata: bezbożność i (21) hańba, i (22) lekceważenie słów zacnych"23.

Powyższy fragment wydaje się mieć charakter eschatologiczny. Zdarzenia W nim przedstawione mają dopiero nastapić w odległej przyszłości (70, 11-12

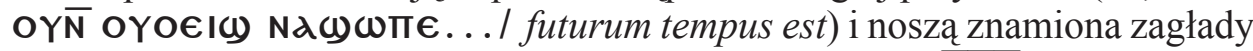
Egiptu. Egipt zostanie pozbawiony boskości (70, 17-18 TMNTNOYT€ ГаP

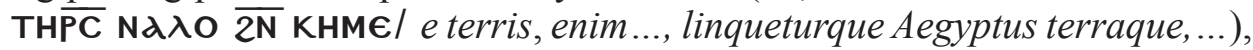
będzie wdową bez swych bóstw. Stanie się to za sprawą „obcych”, którzy przybędą do Egiptu i obejmą nad nim władzę. Nowi władcy nie pozwolą na składanie czci dawnym bóstwom Egiptu. A Egipt, niegdyś najpobożniejszy,

\footnotetext{
${ }^{23}$ Przekład własny autorki artykułu
} 
stanie się w owych dniach ,zagłady” krajem bezbożnym (70, 31-33 $\overline{\mathbf{N}} \times \boldsymbol{\omega}$ -

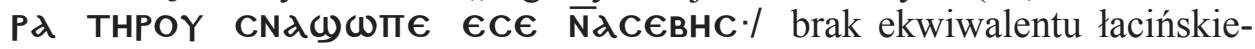
go). Czy można zatem mówić tutaj o monoteizmie, jako wizji świata, która spowodowała chaos w Egipcie? Egipt był niegdyś najpobożniejszy, czyli, zgodnie z pierwszymi wersetami apokalipsy, w czasach, gdy był „światynią nieba", miejscem wielu bóstw, którzy w następstwie przybycia do Egiptu „obcego ludu" zanikaja, dosłownie ,udają się w kierunku nieba” (70, 17-19 TMNTNOYT€... THPC... NCח sura diuinitas), w kierunku którego już nikt nie będzie spoglądał. W wyniku pojawienia się obcej ludności, z nową religią, nastepuje prześladowanie

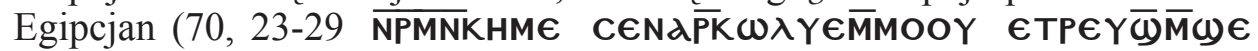

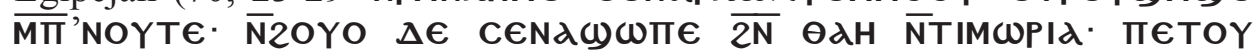

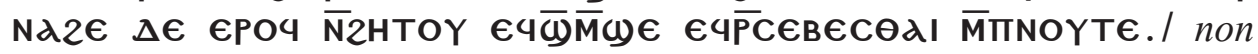
solum neglectus religionum, sed quod est durius, quasi de legibus a religione, pietate cultuque divino statuetur praescripta poena prohibitio). Egipt staje się miejscem niewoli, przyjmując znamiona biblijnego znaczenia Egiptu, jako ziemi uciemiężenia ludności. W tym czasie kraj nad Nilem nie będzie szczycił się świątyniami, ale wypełni się grobami i martwymi ciałami, które to stwierdzenie interpretowane dosłownie może budzić zdziwienie, bowiem Egipt zawsze był pełen grobowców.

Egipt stanie się w czasie chaosu tworem tak dalece niedoskonałym, że nawet barbarzyńca uważany będzie za lepszego i bardziej pobożnego niż

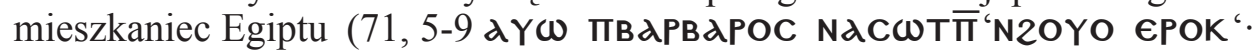

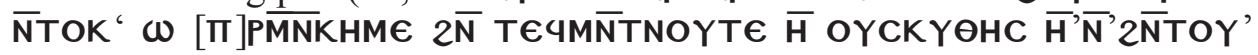

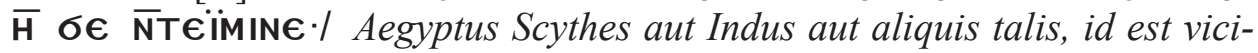
na barbaria), kraju uchodzącego za najpobożniejszy pośród innych państw, Egiptu miłującego bogów (71, 31 кнM€ MMdє INOYT€·/ Aegyptus... divinitatis amantissima), siedzibę bogów (71, 32 пмג $\overline{\mathbf{N}} \omega \omega \pi \epsilon$ NNNOYT€/ deorum in terras suae religionis merito sola deductio), szkołę boskości $(71,33$

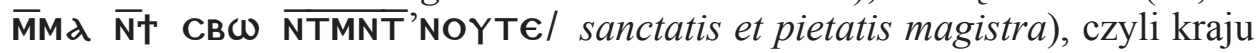
wyraźnie pozytywnego, upadającego jednak pod ciężarem obcej tyranii. Mówienie o barbarzyńcy (Scyt, Hindus) ma znaczenie symboliczne i może być interpretowane jako wskazanie na kraje poza Egiptem, w których występuje politeizm, w przeciwieństwie do opanowanego przez „obcych” Egiptu, nie posiadającego już tylu, bądź takich, bogów co kiedyś.

Ponadto wszystkie dotychczasowe normy, pod wpływem chaosu, zostana odwrócone: ciemność będzie doskonalsza dla ludzi niż światłość, życie zostanie spotęgowane przez śmierć, a człowiek pobożny i dobry postrzegany będzie jako szaleniec i kryminalista $(72,16-26$ c€Nd c€ $\overline{T \pi}$ ' TK גK€ $\overline{\mathrm{N}} 2 \mathrm{OYO}$

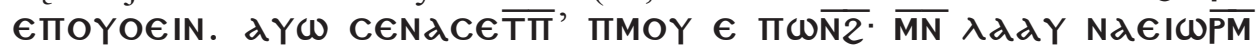

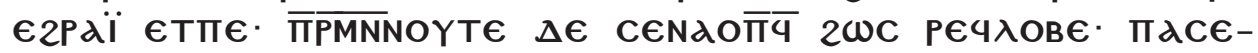

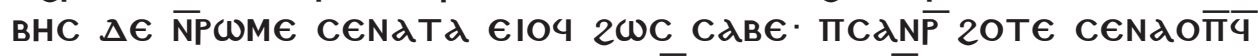

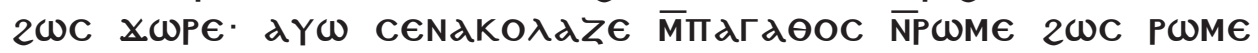


€4200Y.I Nam et tenebrae praeponentur lumini et mors vitia utilior iudicabitur; nemo suspiciet caelum; religiosus pro insano, inreligiosus putabitur prudens, furiosus, fortis, pro bono habebitur pessimus.). Nil, święta rzeka, spłynie krwia, a jej brzegi zapełnią się ciałami zmarłych (71, 17-21 NTTOK'

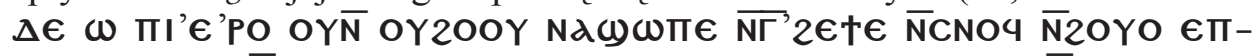

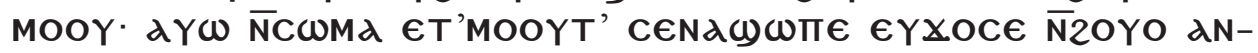
THNE $/$ te vero appello, sanctissimum flumen, tibique futura praedico: torrenti sanguine plenum adusque ripas erumpes undaeque divinae non solum polluentur sanguine, sed totae rumpentur ...). Żyjący w tych dniach będzie bardziej

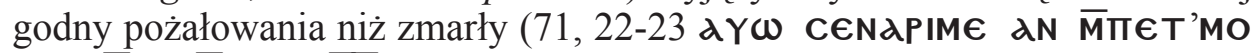

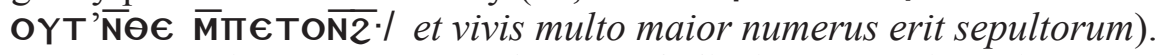

Ta sytuacja nazwana została w apokalipsie „starością świata” (73, 19-

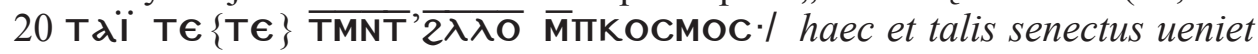
mundi:...), która charakteryzuje się bezbożnością, hańbą i lekceważącym stosunkiem do boskich słów. Jest to wizja chaosu, w odpowiedzi na który bóg, pan i ojciec zniszczy świat doczesny, co pokazują kolejne wersety apokalipsy, zachowane również w języku greckim przez Laktancjusza:

NHC VI,8: 73,23-74,11

$73[\overline{\mathrm{O}}]$

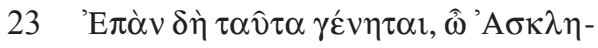

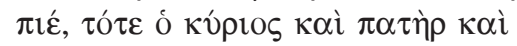

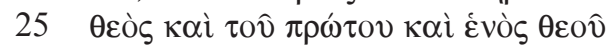

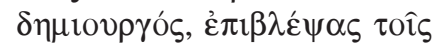

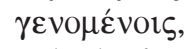

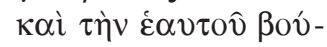

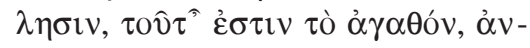

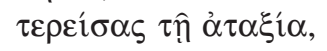

$\kappa \alpha i ̀ ~ \alpha ̉ v \alpha \kappa \alpha \lambda \varepsilon \sigma \alpha ́ \alpha \varepsilon v 0 \varsigma$

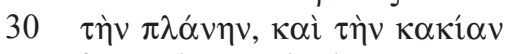

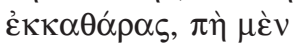

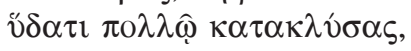

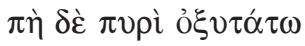

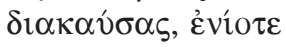

$\delta \dot{\varepsilon} \pi \mathrm{o} \lambda \dot{\varepsilon} \mu \mathrm{or \varsigma}$

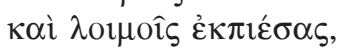

Asclepius Latinus 26
„Cum haec cuncta contigerint, o Asclepi, tunc ille dominus et pater, deus primipotens et unius gubernator dei, intuens in mores factaque voluntaria, voluntate sua, quae est dei benignitas, vitiis resistens et corruptelae omnium, errorem revocans, malignitatem omnem vel inluvione diluens vel igne consumens vel morbis pestilentibus, iisque diversa loca dispersis finiens 
$74[\overline{0} \Delta]$

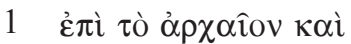

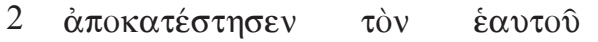

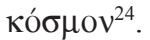

$30[\quad]$

$4 \overline{\mathbf{M}}[\quad \pm 14$

] $\pi € 4$

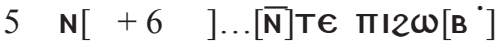

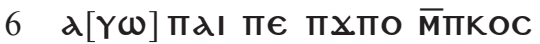

$7 \mathrm{MO}[\mathrm{C}$

T]дாоKגTdCTdCIC $\overline{\mathrm{NT}}$

8 фYCIC $\overline{\mathrm{NN}} \epsilon$ YC€BHC $€$ TNA

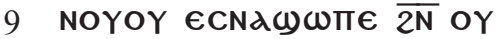

$10 \pi \epsilon P I O \Delta O C \bar{N} X P O N O C \in M$ ad antiqua faciem

mundum revocabit,

ut et mundus ipse adorandus videatur atque mirandus et, tanti operis

effector et restitutor, deus ab hominibus qui tunc erunt frequentibus

laudum praeconiis benedictionibusque celebretur.

Haec enim mundi genitura:

cunctarum reformatio rerum bonarum et naturae ipsius sanctissima

et religiosissima restitutio

percoacta

temporis cursu, quae

est et fuit

sine initio sempiterna".

„(23) Gdy to się zdarzyło, o Asklepiuszu, (24) wtedy pan i ojciec i (25) bóg i pierwszego i jedynego boga (26) twórca, popatrzywszy na to, (27) co się wydarzyło, i z własnej(28) woli, która jest dobrem, (29) sprzeciwiwszy się nieporządkowi, i naprawiwszy (30) błąd, i zło (31) wytępiwszy, albo (32)w dużej ilości wody zatopiwszy, (33) albo w ogniu dotkliwym (34) spaliwszy, niekiedy (35) znowuż wojnami (36) i zarazami pognębiwszy, 74 (1) przywrócił do dawnego (porządku) i (2) swój własny świat. (3) [...] (4) [...] (5) ...dzieła.

${ }^{24}$ Lekcję koptyjską greckiego fragmentu apokalipsy zob. NHS 11, 430-432: (23) €P€ழ dNaï

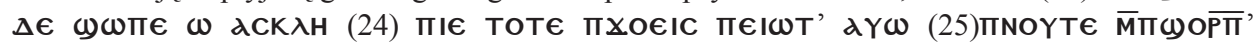

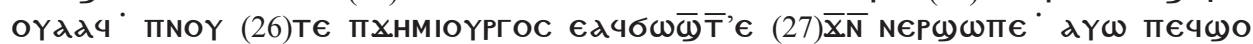

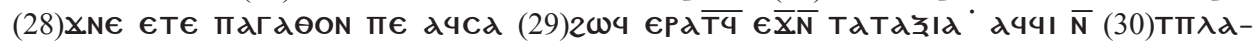

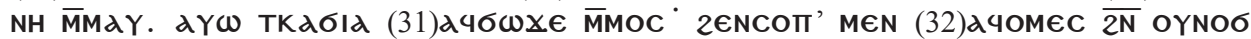

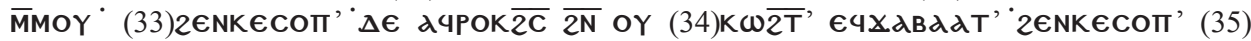

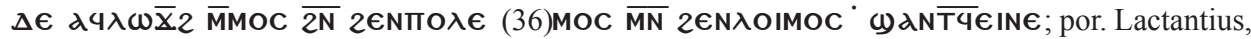
Divinae institutiones VII 18, 3-5; Hermès Trismégiste, ed. A.D. Nock - A.J. Festugière, II, Paris $1947,330$.

${ }^{25}$ NHC VI, 8: 73, 23 - 74, 11, NHS 11, 430-432 (wraz z werrsją łacińską). 
(6) I takie są narodziny świata; (7) powrót (8) natury rzeczy pobożnych i (9) dobrych nastapi w jakimś (10) okresie czasu, który (11) nigdy nie miał początku"26.

Ten fragment daje nam dwie informacje: po pierwsze, mowa jest o jednym

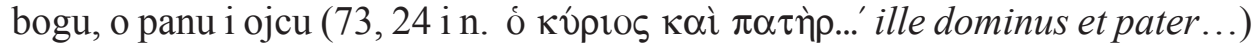
pierwszego i jedynego boga, który to wątek ciagnie się aż do passusu 75,25 i dotyka problematyki gnostycznej, która nie wprowadza istotnych informacji, dotyczących znaczenia Egiptu ${ }^{27}$; po drugie i istotne dla naszego studium, przedstawia narodziny ziemi (74,6-7 пді пє пхто мткосмо[с/ haec enim mundi genitura:...), nowy początek, który jest następstwem minionego chaosu. Ma to swój odpowiednik w wierzeniach Egipcjan, w cyklu śmierci i narodzin ${ }^{28}$. Zgodnie bowiem z kosmogonią egipską, świat nie jest wiecznie młody, ulega z czasem degradacji i musi być cyklicznie odnawiany, czego, według wierzeń Egipcjan, dokonuje bóg słońca Re, który w dzień podróżuje swą solarną łodzią po nieboskłonie, by wieczorem obumierać i schodzić do ciemnego podziemia, tocząc walkę z Apopisem, żeby nazajutrz ponownie się narodzić i powrócić na niebo w postaci tarczy słonecznej i tak codziennie. Nowy porządek nie jest tworzony z ,początku”, co ma wyjaśnienie w mitologii egipskiej, bowiem według niej mityczny moment narodzin świata nazywa się „pierwszym razem” a nie ,początkiem”.

Wizja przedstawiona w tej apokalipsie, jest tragicznym obrazem przyszłości Egiptu. Zaczyna się od niedowierzania Asklepiusa w bóstwa stworzone przez ludzi, z powodu czego Hermes Trismegistos zaczyna egzaltację tradycyjnych

${ }^{26}$ Przekład własny autorki artykułu.

${ }^{27}$ Apokalipsa przedstawia dodatkowo wertykalny przekrój boskiego wszechświata. Począwszy od wersetu 75,8 po passus 75,25 , autor przedstawia kolejne sfery niebiańskie, zamieszkiwane przez bogów. Miejsce najwyższe zajmuje bóg największy, pozbawiony cielesności, siedzący na szczycie nieba w miejscu czysto inteligibilnym, gdzie nie ma gwiazd ani nieba. Miejsce między niebem i ziemią, pod pierwszą sferą planetarna, zajmuje Demiurg - Zeus/Życie, którego epitet utworzony

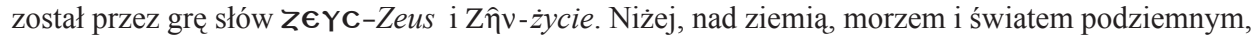
panuje Zeus-Pluton. Bóstwem, które dostarcza ludziom środków niezbędnych do życia, jest Kora, która przewodzi anonimowym orszakiem bóstw lokalnych.

${ }^{28}$ Można zatem mówić o występującym tutaj pewnym cyklu śmierci i powtórnych narodzin oraz odnowienia. Jest to tym bardziej prawdopodobne, ze względu na użycie czasu przeszłego w miejscu, gdzie oczekiwalibyśmy ewidentnie czasu przyszłego (vaticinium post eventum), świadczącego o zdarzeniu, które ma dopiero nadejść. Mamy bowiem fragment następujący: пcon' $\Gamma \mathrm{AP}$

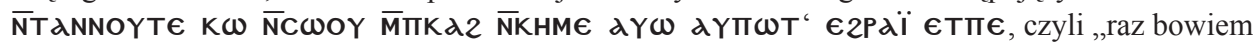
bogowie opuścili ziemię egipską i poszli do nieba" , tutaj występuje czas przeszły Perfectum II

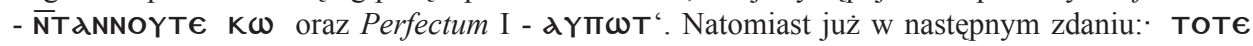

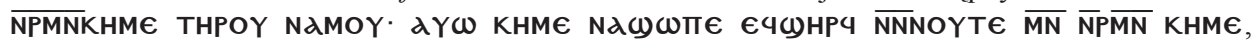
czyli „wtedy wszyscy Egipcjanie umrą i Egipt będzie opuszczony przez bogów i Egipcjan”, występuje czas Futurum I - NגMOY i Nd $\omega \omega \Pi \epsilon$. Skoro więc Egipt już kiedyś został pozbawiony bóstw i ludzi, a autor apokalipsy widzi tego przyszłe konsekwencje i czas zdarzeń wydaje się być spłaszczony, daleka przeszłość i dokonana przyszłość są tuż obok siebie, można więc wysunąć wniosek, że jest to sytuacja periodycznie się powtarzająca, zgodnie z wierzeniami kosmogonicznymi starożytnego Egiptu. 
kultów egipskich, przepowiadając czasy upadku wierzeń Egiptu oraz ich zanik spowodowany kolonizacją obcych ludów.

Apokalipsa niniejsza generalnie nie przedstawia Egiptu jako miejsca grzechu, zła i niedoli. Jest to kraj bogów i pięknych świątyń, co więcej, on sam jest świątynią świata i lustrzanym odbiciem nieba. Nie jest więc jednolicie tożsamy z Egiptem biblijnym, czyli niewolą i złem koniecznym. Ziemia egipska jedynie okresowo staje się miejscem katastrofy moralnej ludzi i upadku bogów. Dzieje się tak jednak z powodu najazdu barbarzyńców, a nie ze względu na etyczne rozpasanie ludności egipskiej. Trismegistos ubolewa nad losami Egiptu, podobnie jak Asklepius, bowiem jego przepowiednia przybiera formę gradacji, widząc coraz gorsze rzeczy, które mają spotkać Egipt. Jest to jednak konieczne dla nastania nowego ładu i przywrócenia porządku w ziemskiej krainie bogów.

\section{$* * *$}

Egipt w „apokalipsie hermetycznej” nie jest jednoznacznym symbolem ludzkiego okrucieństwa, jak w przypadku biblijnej martyrologii żydowskiej w ziemi egipskiej. Bowiem to sam Egipt cierpi z powodu najeźdźców. Dlatego „hermetyczna apokalipsa” daleka jest pod tym względem od znanego nam

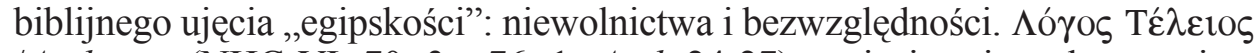
/Asclepius (NHC VI, 70, 3 - 76, 1; Ascl. 24-27), wpisując się w kanon pism hermetycznych, jednoznacznie pokazuje pozytywną stronę wielobóstwa egipskiego. Co natomiast łączy ten pozabiblijny, ewidentnie apokaliptyczny utwór z fragmentem Apokalipsy Eliasza? Można sądzić, że (oprócz typowych cech apokaliptyki, jak przede wszystkim symbolizm oraz vaticinium post eventum czy Chaosbeschreibung) struktura wypowiedzi. „Apokalipsę hermetyczną”, jak i Apokalipsę Eliasza, generalnie można by podzielić na dwie części. Pierwsza to obraz upadku Egiptu (np. Nil spłynie krwią) i jego zniewolenia przez lud spoza

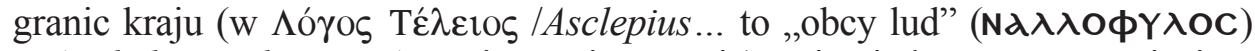
w Apokalipsie Eliasza to Asyryjczycy iPersowie), cojestjednoznacznezpojęciem Egiptu jako kraju niedoli i chaosu. Druga część natomiast stanowi wyzwolenie z bezładu i śmierci, co w ,apokalipsie hermetycznej” przedstawione jest jako „nowy początek świata”, sprowadzony przez boga - pana i ojca, natomiast w Apokalipsie Eliasza chaos poskromiony ma być przyjściem ,prawdziwego Pomazańca" - gołębicy, stanowiącego przeciwwagę "syna bezprawia" panującego w Egipcie. Pod tym względem można by spekulować o tożsamości

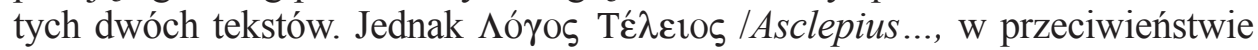
do Apokalipsy Eliasza, rozpoczyna się swoistą apoteozą Egiptu (70,3 i n.), która wyrażana jest również w wersetach późniejszych $(71,31 \mathrm{n})$, w postaci określeń: Egipt - ,miłujący bogów”, "szkoła boskości” czy „,siedziba bogów” i dzięki owej hiperbolizacji, Egipt w ,apokalipsie hermetycznej” staje się krajem, w gruncie rzeczy, idyllicznym, a już z pewnością względnie pozytywnym, różniącym się od Egiptu apokaliptyki pisanej zgodnie z nurtem biblijnym. 
THE MEANING OF EGYPT IN THE APOCALYPSE

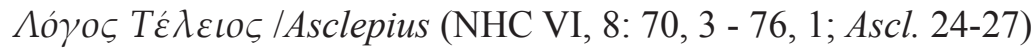

(Summary)

The aim of this paper was to present the Egyptian land in two apocalyptic texts both written in a Coptic language. First - the Apocalypse of Elijah (written in two Coptic dialectical versions: Sahidic and Achmimic) - shows a typical biblical meaning of Egypt as a place full of pain, death and fear. On the other hand, in the Codex VI of the Nag Hammadi Library there is the Apocalypse which gives us quite different image of that part of African land. This very Apocalypse is called the Apocalypse of Hermes Trismegistos or the Hermetic Apocalypse (written in Sahidic dialect and partly in the ancient Greek, whole test is composed in a Latin version and attributed to Ps-Apuleius of Madaura). Here, Egypt seems to be a paradise - image of heaven, land of gods and beautiful temples. But suddenly, that peaceful part of the world turns into "hell" with death, blood and pain - just like in the Apocalypse of Elijah. Our purpose was to analyze those two Coptic Apocalypse, compare the results and finally, try to find the answer on the basic questions: Egypt - heaven or hell? Could it be that this land was full of blood because of monotheistic religion? 
